\title{
Towards an Overview of Nūrsī Studies in India
}

\author{
Dr. Muhammad Dawood Şofi \\ Post-Doctoral Candidate, International Relations, Ankara Yildırım Beyazıt Üniversitesi (AYBU) \\ Ankara, Turkey \\ Email: sofidawood@gmail.com
}

Showkat Ahmad Dār

Ph. D Islämic Studies, Aligarh Muslim University, Aligarh, India; Contractual Lecturer

Government Boys Degree College Pulwama, Kashmir

\begin{abstract}
:
The impact of Said Nürsī and his movement has virtually crossed geographical boundaries and has made inroads in various regions and continents, including South Asia. In this direction, this paper makes an overview of various fields of activities on Nürsi Studies in India - a country home to the one of the largest Muslim communities lliving as minorities) in the world - ranging from conferences, symposiums, workshops to translation, research, Dersāne gatherings, and inclusion of Said Nürsi in the curriculum. The paper focuses on the developments of Nürsi studies in India that took place in the beginning of the second decade of the twenty-first century. It also analyses how Said Nürsì was introduced in India and how Indian people reacted to his message and mission.
\end{abstract}

Keywords: Said Nürsī; IFSC; Able Children of Islām; Dersāne; Risāleal-Nūr; Peace; Harmony

\section{Introduction $^{1}$}

Contemporary World is experiencing serious crisis not circumscribed to few regions or communities or religions as such but engulfing the humanity globally. In order to rectify these problems and put things in order Said Nürsì (1877-1960) among others devoted himself for the wellbeing of Muslims in particular and humanity in general. He with his extraordinary intelligence and debating skill, unusual memory, and tremendous talent toward learning, caught the attention of one and $\mathrm{all}^{2}$ and consequently attained the title of 'Bedīuzzamān' (The Wonder of the Age $)^{3}$. Yearning to convey the message of Islām to the whole world and dispel the darkness of the modern age, he wrote his magnum opus Risāleal Nür, a modern commentary of the Qur'an. At a critical juncture of the history, he along with his disciples carried on the mission of enlightening people with the message of Islām and while doing so they (especially Said $N \bar{u} r s \bar{l}$ ) faced harsh treatment from the then government. However, the light lit in Turkey by Said Nürsi-whose firm resolve authorities failed to 
break-is now enlightening the whole world. The dream he saw and the mission he started and lived for is being rigorously carried forward by his sincere and devoted followers. Impact is very apparent as we encounter an increase in the readership of Said Nürsi for his writings are being translated into different languages of the world. His message and thought is spreading at a very rapid pace and the full credit goes to the Istanbul Foundation for Science and Culture, Turkey (hereafter abbreviated as IFSC) which is frequently organizing among others, conferences, seminars, workshops, summer schools on the one side and translating his works in various languages on the other side.

Among other countries of the world, India too welcomed the message of Said Nürsì who was initially "highly influenced by Imām Rabbānī Shaykh Ahmād Sirhandī (d. 1624 CE) and his Maktüb 'ät". ${ }^{4}$ It is perhaps after seeing the stature of the latter that the former termed Indian people as "An Able Son of Isläm" or the "Able Children of Isläm". ${ }^{6} \mathrm{We}$ witness that from the last four or five years Said Nūrsî's personality attracts the masses of India so much so that they are now deeply engaged and involved in knowing him and the thoughts he propounded. Here, it is also important to point out that prior to this-as the influence was almost negligible-a meagre numbers of the people were aware about his thought and personality. Dr Obaidullā'h Fahad (Associate Professor, Aligarh Muslim University, India) is one among those few who has come out with a book published long back in 1998 under the title Jadid Turki Mein Islāmī Baydārì. ${ }^{7}$ One of its chapters (Shaykh Badī'al-Zamān Said Nūrsì aur Unkī Ișlāhi Judu Jahad) is devoted to his life, thought, and reform activities. $^{8}$

One of the very significant reasons for the spread of Said Nürsì's message in India, apart from those discussed, is his relation with Imām Rabbānī $\square$ Mawlānā Shaykh Aḥmād Sirhindī. In the works of Said Nūrsī, there is every now and then the mention of Imäm Rabbanni and such a thing perhaps connotes that Said Nürsi might have been inspired by this great scholar to a large extent. Obviously, this relationship seems to be decisive when one attempts to find the answer of the question that what are the decisive factors that attract the people of this region? Another critical factor in this direction, perhaps may be, his vision regarding Islām and the issue of modern science and technology. His keen interest to reconcile faith and reason, and Isläm and science ${ }^{9}$ plus invoking the Muslims to study meticulously modern science and its underpinning values so as "to appreciate the Creator better" 10 also strikes the minds of the people. 
The credit of keeping this interest alive and in consolidation of Nürsī's readership among masses goes to the system of Dersāne. ${ }^{11}$ The Dersanne culture that has been introduced in India by the followers of Nür Movement is been conducted on weekly basis at various places in Delhī including the academic hubs like Jawähar Lal Nehrü University ${ }^{12}$ and in Jamia'h'h Millia'h Islämiya. ${ }^{13}$ Moreover, these gatherings are also held in the south of India-Kerālā. These activities obviously are strong reasons among others that are helping in the dispersal of the message of Said Nürsi in India. It is also to mention that these Dersāne gatherings are not only meant for Turkish expatriates but Indians are also involved in them as well. Dersanne is meant: to cultivate the inner life and to prevent the penetration of modern skepticism and materialistic ideologies; and to place the Qur'an at the centre of social interactions and adopt the modern changes by reviving the shared Islamic clusters. Its other important objectives are to facilitate the dissemination of Said Nürsì's life and thought and also give a concrete shape to Said Nürsì's discourse. ${ }^{14}$ It can be said that these gatherings are becoming a new public ground to socialize with people and exchange ideas, values and opinions of one another.

One and all; the intellectuals, academics, scholars, and the students actively participate in the activities (especially conferences and symposiums) related to Said Nürsi. They not only strive to understand his message but also endeavor to spread it among the natives in their own mother language (Urdī, Kashmirī, Hindī etc). In the following pages, a brief description is given about the activities related to Said Nürsi like the conferences organized, themes touched, scholars involved, papers on diverse subjects presented and published and the influence produced.

\section{Symposiums, Conferences, and Workshops on Said Nürsī and Risāle- al- Nūr}

It has been already mentioned above that IFSC is probably the only organization which is actively engaged in this wholesome affair. Even if there might be some miniature activities related to Nüsrī Studies in India performed earlier, but it is only from the year 2012 onwards, as is palpable enough, that a major impact has been laid. In this regard, Conferences, Workshops, and other related activities have proved far more effective in recrudescing the interest and enthusiasm among the Indian people. Its emblematic is the huge participation of students, scholars, intellectuals, and experts alike in these events. For example, Dr. Obaidullä'h Fahad ${ }^{15}$ (Aligarh Muslim University) and Prof. Hamìdulla' 'h Marāzī (University of Kashmir) who amid being profusely engaged in 
their scholarly workings also frequently participate in these events whether organized in India or abroad. The latter's work on Said Nürsì titled The Relevance of Nürsì to Modern Times: A Study of Intellectual Paradigm is under print and is hoped that very soon the readers will extract benefit from it. ${ }^{16}$

\section{Risāle-al Nür, Faith, and Multiculturism}

For the first time in India, two symposiums on Said Nürsì and his magnum opus Risāle-al Nūr were organized in Kerālā, India on 29 and 30 January 2012. Organised at Dār al-Hudā Islämic University, Kerālā under the theme Risāle-al Nür and Isläm in Modern Turkey, the first event witnessed the participation of more than 1000 master and PhD students. ${ }^{17}$ On the very next day at the same place but at a different institution namely Jamiä'h Markazu al- Saquafathi al- Sunniyya, ${ }^{18}$ another symposium titled Living in Faith and Peace in a Multi-Cultural World: Risāle-al Nür was held. Amid witnessing the participation of about 10000 people, the gathering was graced with the august presence of some reputed dignitaries like inter alia Sri Lankan Minister of Education, Riza Akcali, Ex-Minister of Turkey and Prof. Dr. Abdulhakim el-Enis who enlightened the participants with their views about Bediuzzamān Said Nūrsī and his Risāle-i Nūr. ${ }^{19}$

\section{Peace and Harmony in a Multi-Cultural World and Risäle-al Nür}

Marching from south India and reaching to north India, IFSC continued its endeavour to familiarize the masses vis-wazan-vis the persona of Said Nūrsī with an objective to disseminate his teachings thereof. It is in this background that the $1^{\text {st }}$ International Conference on Said Nūrsī and his Risāle-i Nür took place in one of the leading institutions of higher learning in India namely Jawaharlal Nehru University (JNU), New Delhi on 1-2 February, 2012. ${ }^{20}$ The conference "Living in Harmony and Peace in a Multi-Cultural World: Risāle-al Nür" was a joint venture of the Centre of Arabic and African Studies, School of Language, Literature and Culture Studies, JNU, New Delhī and IFSC. ${ }^{21}$ The conference was attended by delegates from the places as far as UK, USA, Canada, UAE, Turkey, Lebanon etc. Research scholars and students from JNU, Delhī University, Jamia'h'h Millia'h Islämia'h (JMI) and Aligarh Muslim University (AMU) not only attended the conference but also actively interacted with the academicians and scholars of high repute from India and abroad; thus broadening their vision, enlightening their character, and infusing in them new vistas multifariously. ${ }^{22}$

Prof. Dr. M. Aslam Islāhīi in the inaugural speech espoused: 
"We are glad to introduce such a figure who appeared 100 years ago with his ideas. It was not useless that he was given the name 'Bediuzzamān-Wonder of the Age,' because he suffered a lot, then deserved this title." ${ }^{23}$

Shri Arif Mohammad Khān, Former Union Minister of India said:

"I made a research about Risāle-i Nūr, read it and I can describe Risāles as 'Barakath-ul Qur'ān'."

With reference to India, he said that the place is known for its long cherished practice of pluralism as it has received the Persians, Jews, Christians, and Muslims. India does not just tolerate pluralism rather welcomes and practices pluralism. Moreover, according to him the teachings of Bedīuzzamān about human cooperation, mutual love, coming together of human beings etc will commence from this land of pluralism and diversity and will therefore add further significance to these values. In the same vein, Dr. Mujīb-ur Rahmann (coordinator of the symposium) delivered an informative speech wherein he said:

$N \bar{u} r s \bar{\imath}$ is not known in India and unfortunately India is unaware of Nürsì's dynamic approach in his commentary. There are a lot of things that we should learn from him. ${ }^{25}$

It seems that the aim and objective of organizing such a grand conference on the apt title and at the apt place was not only to make contribution to the field of learning but also to deliberate upon the relevance of ideas of peace, harmony, meaning and significance of faith in life, peaceful co-existence, interfaith dialogue, pluralism etc in a multicultural environment like India with special reference to Said Nürsì. The titles of the technical sessions, diverse in nature, viz The Methodological and Educational Aspects, Modernity; Globalization and Reform; Human Nature, Faith Youth and Women's Issues; Contribution of Nürsī to Change and other Issues; Interfaith Dialogue and Pluralism; Spirituality, Revivalism and Reform; Dialogue and Co-existence etc itself speak about the areas touched and the themes resonated.

\section{Isläm, Modernity, and Said Nürsī}

The mission of familiarizing and disseminating the message of Said Nürsi to the people of India at the behest of IFSC continued unabatedly. In February 2013, the same organization organized another International Conference in collaboration with Zakir Husain Institute of Islämic Studies, JMI, New Delhī. Islām and Modernity: The Perspective of Bediüzzaman Said Nürsì was chosen as the theme of the Conference 
and the Scholars, academics, and intellectuals presented their views on the topic diversely. ${ }^{26}$

In the contemporary times, the issue of Isläm and Modernity dominated and dominates discussions in the religious and academic field. The event, as the fitting title suggest, provided an opportunity to listen to the prolonged presentations, discussions, and speeches on the nature of Isläm-Modernity dichotomy.

Among the other participants, the main characters who addressed the audience were Dr. Burāk Akçapār (Turkish Ambassador in India), Prof. Akhtar ul Wāsey (JMI, New Delhi), Prof. Faris Kāya, Prof. Dr. İbrahim Dzdemir (Rector of Hasan Kalyoncū University, Gaziantep, Turkey), Mr. K. Rāhman Khān (former Union Minister for Minority Affairs), Prof. S. M. Rashid (former Pro Vice Chancellor JMI, New Delhi) etc. $^{27}$ They in their speeches while stressing on the thought and contribution of Said Nürsi also emphasized on the relevance of his teachings to the present times. They further upheld that his teachings act as panacea in modern world which is full of chaos and confusion. ${ }^{28}$ Moreover, his vision, approach to look at the realities, response to the challenges like the modernity were among other subjects discussed extensively in the conference.

Moreover, collection of $\bar{U} r d \bar{u}$ papers presented in the conference has been published in a book form by Al-Balagh Publications, New Delhi under the title Mu'ällim-al Așr: Said Nürsì. Prof. Akhtarul Wasey who has edited this book writes about its significance in the Preface that:

We hope this book will be helpful to comprehend Said Nürsì's thought in the sub-continent and for the Urdu readers it will prove an excellent source and channel for the introduction of life and contribution of Said Nürsī [authors' translation]. ${ }^{29}$

\section{Glimpses of Knowledge, Faith, Morality and Humanity in Risāle-al Nür}

Aligarh Muslim University, the fountainhead of Sir Sayyìd Ahmäd Khān, witnessed the holding of $3^{\text {rd }}$ International Nürsi Studies Conference from 11-13 February 2014. The conference which spanned for three days was organized by Department of Islāmic Studies, Aligarh Muslim University, Aligarh (AMU) in collaboration with IFSC on the fitting title, The Risāle-al Nūr: Knowledge, Faith, Morality and the Future of Humanity. The credit for organizing such a grand international event goes especially to Prof. Faris Kāya, Hakān Glurece, Ihsā̄n Altintās, Dr. Obaidullah Fahad (Convenor), Dr. Abdul Majid Khān (Co-convenor), Dr. Bilāl Ahmäd Kutty, Dr Ziauddin Malik and the University Administration. 
It attracted the attention of the wider sections of the Indian society when Milli Gazette (a fortnightly paper) further publicized the event. The column read:

Aligarh: A three-day conference on the works and struggle of Turkish thinker and reformer Badīūzzamān Nürsī (1877-1960) was held by the AMU Department of Islāmic Studies in cooperation with Istanbul's Foundation for Science \& Culture (FFSC), during 11-13 February. Delegates from Indian universities as well as Turkey, Jordan, Algeria, Saudi Arabia, Yemen, Iraq, USA and Malaysia participated in the seminar. Speakers included Nadwat - al Ulamā's Shaikh Sayyid Sulaimān Nadwī who said that Nürsì's treatises positively affected the recent Egyptian history. The Arabic translator of Nürsì's Risäleal Nūr, Dr Qasim Sālehī said that while reading these treatises one feels as if he is witnessing the age of early Islām with his own eyes. Algeria's Māmön al-Jarrārr [actually from Jordan] said that Nürsi's treatises have played a historic role in changing and correcting people's outlook. ... Professor Faris Käya of Turkey (from FFSC) was one of the participants. He invited people to study Nürsì's treatises which stress on kindness, shūrā and positiveness. ${ }^{30}$

Besides Inaugural (held at the University's famous Kennedy Auditorium) and Valedictory Sessions, a total number of 12 plus 9 parallel Business Sessions were held. Presentation of more than 100 papers, explored, examined, and highlighted diverse dimensions of Said Nürsì and his magnum opus, Risāle- al Nür. The scholars highlighted the vision and role of Said Nürsi in revitalization of Islämic faith in the dark ages of Islämic caliphate. The intellectuals of high repute like Mawlāna Sayyìd Salmān Nadwī, Prof. Faris Kāya, Dr Mamön Jarrār, Dr Ozgler and others presented their views multifariously on the life, thought, and works of Said Nürsì. Deviating attention of the listeners toward Said Nürsì's struggle, the scholars endeavored to strengthen faith, morality, and brotherhood among the believers.

Gracing the occasion, Vice-Chancellor Lt. General (Rtd.) Zamir üddin Shāh (AMU) in his presidential remarks while highlighting the inevitability of reorienting 'Education' with 'Faith' emphasized on the adoption of education as a source for upholding 'Truth' and 'Justice'. He further espoused that in such efforts Aligarh should play the role of the vanguard. ${ }^{31}$ The special lecture of Pro Vice Chancellor Sayyīd Ahmad Alì 
(AMU) and of Prof. Faris Kāya which they delivered in the Valedictory Session of the Conference summarized on the one hand the entire theme of the Conference and on the other highlighted the necessity and inevitability of spreading the vision of Said Nürsi. ${ }^{32}$

\section{IFSC's Mission Continues: The Concept of Qur'än in The Risāle-al Nūr}

IFSC's mission continues. As the organization is very much engaged in conducting another conference of the series; the preparations of which were in full swing. While emphasizing on the thought and mission propounded by Said Nürsī, the $4^{\text {th }}$ International Nürsì Studies Conference focused on the topic-as proposed by the organizers-The Concept of Qur'än in The Risäle-al Nür held on 12-13 February, 2015. Wahy, Tafsir, Mufassirin, their approach to Tafsìr, views on the issues of Tawhìd, Risāla'h, Akhirā'h, Mi'räj etc. with a special focus on The Risāle-al Nür of Said Nürsì were the spotlight subjects of the event. $\bar{A} l i a \bar{a} ' h$ University, Kolkata hosted the event in collaboration with IFSC, thus, widening the readership of Said Nürsi in India. ${ }^{33}$ The conference attracted many national and international academicians who participated and presented their papers in the well-organized business sessions. ${ }^{34}$ Thus, $\bar{A} l i \bar{a}^{\prime} h$ University had the opportunity to contribute variously to a very vital field of learning having inexplicable significance when it comes to the main sources of Isläm.

In the second month of the year 2016, IFSC conducted the $5^{\text {th }}$ International Conference in the southern part of India. This time IFSC organized the event in collaboration with the Department of Arabic, Kerālā University on 8-9 February 2016. The conference focused on its proposed theme, "Education \& Ethics in Said Nürsī's Risāle-al Nür." The conference focused on the importance of education in the in human life, need of moral-based education, integration of knowledge and other dimensions with reference to Said Nürsì and his Risāle-al Nür.

IFSC's tight schedule of activities in India to disperse the message of Said Nürsī is evident as it conducted in the very next day another International Nūrsì Studies Seminar in Mumbai. India is a multi-cultural and multi-religious society and in fact, to live a peaceful and pleasant life is very difficult in such societies. The theme, Living in Peace \& Harmony in a Multi Cultural Society: From The Perspective of Said Nürsī's Risāleal Nür for the seminar held on 10-11 February 2016 reflects the significance of the subject and its apt relevance in the contemporary times. ${ }^{36}$ 


\section{Risāle-al Nūr Workshop: Role and Place of Said Nūrsì’s Thought in 21st Century}

Continuing the mission, IFSC conducted a two day international workshop on Bedīūzzamān Said Nūrsī and his Risāle-al Nūr with the support of Department of Islämic Studies, Islämic University of Science \& Technology, Kashmir (IUST). Although the purpose, was as per the organizers, to "establish dialogues among intellectuals and students, to share the knowledge, to explore the objectives and challenges of the modern society" ${ }^{37}$ but it looks as if the chief aim of the event was to introduce the personality, mission, and works of Said Nürsi among the students and research scholars and thereof inculcate in them the values and principles the man lived for.

The occasion was graced by the presence of a good number of reputed and revered intellectuals like Prof. Yünus Cengel, Dr Iḥsān Colāk, Dr Necātì Aydīn, Prof Talāt Ahmad, Prof. Hamidullā'h Maräzì etc who irradiated through their deliberations, lectures and speeches the various dimensions of Said Nürsì's life and thought. For example, Prof Talāt Ahmad, Vice Chancellor of JMI, New Delhi, in his address, amid deliberating upon the teachings of Said Nürsì stated that the "contribution of this [great] Turkish [reformer] was relevant and imperative [religiously] and [politically] to the present day ... scenario across the Muslim world. ${ }^{38}$ He continued to point out that "In the age of inter-religious, intra-religious and regional conflicts, the teachings of Nürsi in general and the workshop in particular have great relevance to address many issues." 39 Prof. A.R. Trag, Vice Chancellor of IUST, spotted out that Nürsì by way of logic and reasoning conveyed the message of Isläm to the followers of other faiths. ${ }^{40}$ Moreover, Prof. Faris Kāya, the secretary of IFSC, and Prof. Hamìdullä'h Marāzi gave a detailed account of life, works and thought of Said Nürsì, wherein they mainly highlighted his struggle, contribution and selfless dedication to the cause of Islām.

Students and scholars who actively took part in the entire workshop also presented their papers highlighting various aspects of Said Nürsì. Moreover, IFSC enriched the Library of Islämic Studies Department of the University of Science and Technology with two sets of Risāle-al Nūr Collections (English and Arabic) and other relevant books on the subject. It was decided that the University will not only establish a 'Nürsi Corner' at the Library but will also initiate student-faculty exchange program. ${ }^{41}$ 


\section{Other Fields/Activities}

Apart from conferences, symposiums, and workshops; there are other relevant and important mediums contributing to a great deal to the field of Nürsì Studies in India. They include, among others, Barla Publications, New Delhi, Dersāne gatherings, recent introducing of Said Nürsì: Life, Thought, Works, and Movement in the curriculum of the subject of Islämic Studies, ${ }^{42}$ translation of his works (in the local languages of Urdu, Kashmiri, Hindi, Bengali, Gujrati, and Malyalam), ${ }^{43}$ write-ups, and research papers published in various newspapers, magazines, and journals. A special issue of Islām aur 'Așri Hâdir "Islām and Modern Age" (quarterly journal of Department of Islāmic Studies, JMI) dedicated to Mu'allimi 'Așr: Sa'id Nürsì (Said Nūrsī: A Contemporary Scholar) is a significant example in this regard. Abdul Rashīd Āfāq from Kashmīr is engaged in translating the works of Said $N \bar{u} r s \bar{i}$ into Kashmiri language with an aim to disseminate the message of this Turkish reformer among the Kashmirī masses. He has translated a book of Said Nürsī into Kashmiri under the title Hashr teh Akhrät. Similarly, Hafiz Muhammad Ahmad Nadwī and Dr Nasim Akhtar Nadwī have rendered the Life of Said Nürsi in Urdu Language under the title Dastan-al 'Azm wa Imān: Bedīuzzamān Said Nūrsì ki Mukhtașar Sawāniḥ Hayāt. In short, the website of Barla Publications updates the new readings in various Indian languages and so far it displays that the teachings of Said $N \bar{u} r s i \overline{~ h a v e ~ b e e n ~ t r a n s l a t e d ~ i n t o ~ s i x ~ I n d i a n ~ l a n g u a g e s ~ w h i c h ~ i n c l u d e ~} 12$ in Urdu, 5 in Bengali, 1 each in Kashmiri, Malayalam, Hindi, and Gujarati. ${ }^{44}$

In the recent years, it is also witnessed that research students are showing more than normal interest in those topics which in one way or the other are related to Said Nürsī. The names of Zubair Hamid (AMU), ${ }^{45}$ Irfän Jalāl (IUST), ${ }^{46}$ Gowhär Qadrī Wanī (JMI) ${ }^{47}$ etc are the evidences that generalize and verify the statement thus made. Regarding inclusion of Said Nürsī and his Movement in the curriculum of the Universities like AMU and JMI, it is to say that it is one of the topics incorporated recently in one of the papers related broadly to Muslim Reform Movements and Thinkers. Moreover, this paper is for MA students and is compulsory as well. $^{48}$ In addition, the research scholars working on the various dimensions of Said Nusri's thought and methodology adapted in interpreting the Qur'an and in understanding what Nürsī calls 'the book of nature'. A glimpse of this fact was seen when Dr. Obaidullah Fahad published an edited book titled "Faith-Knowledge: Perspectives of Said $N \bar{u} r s \vec{\imath}$ " containing 32 papers by the various scholars from different fields. ${ }^{49}$ 


\section{Conclusion}

Bedīüzzamān Said Nürsī-the Turkish reformer-pioneered a movement both practically as well as intellectually with an aim to enlighten and reform the Muslim society at a critical juncture of the history. A mission for which he devoted his entire life, faced so many hardships, and even rejected the government's portfolio is carried forward vigorously, earnestly, and enthusiastically by his ardent followers. We observe that they are endeavouring to go beyond Turkey and propagate his message at a global level. ${ }^{50}$ From the last three or four years, IFSC is yearning heavily to struck Said Nürsì's chord among the Indians. While discoursing inter alia on the vital subjects and expressions of faith, morality, peace, reform, pluralism, brotherhood, coexistence, knowledge, and spirituality, IFSC is aspiring to strengthen faith, re-invigorate morality, re-energize religious fervour and revive the society.

In India, acquaintance with the works of Said Nürsī, as is observed, has enhanced the interest of people to know and study him. The impact is evidenced by the overwhelming participation in these academic cum reform events. However, it is also very important to mention that in India before commencing of these conferences, workshops and other activities there were very few who had conversancy of Said Nürsì. Therefore, it is apt to state that it is the aftermath of these conferences that more and more people amid getting involved in reading Said Nürsì's message are producing books, research papers and articles of great literary taste touching various dimensions on the one side and spreading his thought on the other side. Moreover, selecting research topics related to Said Nürsì (as is seen) by those pursuing $\mathrm{PhD}$ (as their number goes on increasing in India) reflects the growing zeal to study him among the young scholars. In short, it can be said that Nürsì Studies in a very short span of time gained much prominence, wherein its influence spread like a river in India and in the future it is expected, seeing the extent of its impact on the region, that discourse in religious and academic circles will be dominated by the Nürsi element. Last but not the least, IFSC's role-which needs full appreciation in being remarkable (in its ways and methods) in travelling beyond the boundaries of Turkey-will be decisive in the future course of Nürsi Studies in India.

\section{References \& Endnotes}

${ }^{1}$. Most of the information given in the paper is predominantly taken from the website of IFSC, conversation with Prof. Hamidullah Marazi (Kashmir), Prof. Obaidullah Fahad (Aligarh), Hakan Gulrece and Ihsan 
Altintas (Turkey), Ibrahim Ahmet and Muhammad Akif (New Delhi). The authors have collected information from them either through email or personal conversation. They wish to extend and express their in-depth gratitude to all of them for their frequent response and for providing the much needed guidance, requested information, and relevant material as well. We are also thankful to our mentor and supervisor Dr. Abdul Majid Khan who always encourages rather incites us to take such academic propositions.

${ }^{2}$ Bediuzzaman Said Nūrsi, The Damascus Serrmon, tr. Şükran Vahide (Ankara: Ihlas NËr Nesriyat, 2004) p. 4

${ }^{3}$ Molla Fatah Allah of Siirt presented him the title because of his exceptional ability and the speed with which he mastered different sciences.

${ }^{4}$ Dr. Abdul Majid Khan, "Welcome Address," Conference Magazine, IFSC, Year: 6, Issue: 21, March 2014 (Istanbul: Mega Basim, 2014) p. 5

${ }^{5}$ Mehmet Firinci, student of Bediuzzaman said this in his speech in the 'Inaugural Session' of the conference held at AMU's Kennedy Auditorium. The authors were also present in that session as well. See also Conference Magazine, op. cit., p. 10

${ }^{6}$ Prof. Faris Kaya gave a mention of it in a speech which he delivered in the 'Inaugural Session' of the conference held at AMU's Kennedy Auditorium. See also Conference Magazine, op. cit., p. 12

${ }^{7}$ Obaidullah Fahad, Jadīd Turkī Mein Islāmī Baydārī (Delhi: Hilal Publications, 1998),326 pp.

8 Ibid., pp. 27-108

9 Isra Yazicioglu, "Perhaps Their Harmony is not that Simple: Bedīūzzamān Said Nūrsi on the Qur'ān and Modern Science," Theology and Science, vol. 11, no. 4, 2013, 339-355, 342

${ }^{10}$ Ibid.

${ }^{11}$ Assembling together and then reading Said Nürsi's works is what is called Dersane. Mustafa-one of the followers of Said Nürsi who lives in Delhi-revealed (when asked about these gatherings) that we use to read one chapter from Risale-i Nür after every Salah. ${ }^{11}$ So, it therefore, implies that these gatherings are a means of communicating Said Nürsi's message to the others. Personal conversation of the authors with Mustafa Culfa, January 9,2015

${ }^{12}$ On 20/04/2015 in the evening I, Mohammad Dawood also attended the gathering in this University in a room of Lohit Hostel occupied by a Turkish student namely Sardar and it continued for about more two hours. 
${ }^{13}$ Personal interaction of Mohammad Dawood with Ibrahim Ahmet, Delhi on $21 / 04 / 2015$

${ }^{14}$ M. Hakan Yavuz, "Print-Based Islamic Discourse and Modernity: The Nūr Movement," Third International Symposium on Bediuzzaman Said Nürsi, 24-26 Sep 1995, pp. 8-9; retrieved from http://www.iikv.org/ /index. /sympeng/article/view/917/1140 (08/01/2015)

${ }^{15}$ In an interview with the authors, Dr Obaidullah Fahad while sharing some significant information related to the subject also revealed about that he is working on Said Nūrsi especially from last three or four years and very soon his book on this great reformer, touching some important aspects, will be published. Interview with Dr Obaidullah Fahad, AMU, 1 January 2015.

${ }^{16}$ In a conversation, Prof. Hamidullah Marazi said that he has not only participated in almost all the events organized by IFSC in India but has also presented his papers highlighting some critical subjects like Western and Islamic Civilisation, Social Change, Prophethood, Philosophy, Theology, Sufism, and The Relevance of Nürsian Thought to Modern Times. He has also chaired some sessions of these events in India and abroad as well. Email conversation(s) with Prof. Hamidullah Marazi, 0407 January 2015

17“"India Welcomed Risale-i Nūr," IFSC, 24 April 2012, retrieved from http://www.iikv.org/en/india-welcomed-risale-i-Nūr accessed on 20 December 2015

18 Jamia Markazu Ssaquafathi Ssunniyya (estd. 1978) is a leading academic and prestigious charitable Islamic University in Kerela (India) that plays a key role in revival activities. See for more details http://markazonline.com/en/history/ accessed on 07 January 2015

${ }^{19}$ India Welcomed Risale-i Nūr," op . cit.

${ }^{20}$ Ibid.

${ }^{21}$ "Seminars \& Conferences," JNU NEWS, retrieved from http://www.jnu. ac.in/JNUNewsArchives/JNUNews_Mar_Apr12/conferences.htm ccessed on 21 December 2014

${ }^{22}$ Ibid.

23 India Welcomed Risale-i Nūr," op. cit.

${ }^{24}$ Ibid.

${ }^{25}$ Ibid.

${ }^{26}$ It was a two day conference held on 8 and 9 February 2013. For more details on this, see http://www.iikv.org/en/islam-and-modernity-a-twoday-conference-in-india-and-turkey 10/11/14 
27 "Jamia Millia hosting international conference on 'Islam and Modernity'," Muslim Mirror, 8 February 2013, retrieved from http://muslimmirror.com/eng/jamia-millia-hosting-internationalconference-on-islam-and-modernity/ accessed on 25 December 2014

${ }^{28}$ The lectures and speeches of these personalities were published in the Conference Brochure, Islam and Modernity: The Perspective of Bediuzzaman Said Nürsi, available online at http://www.iikv.org/images/tools/bulten/16.pdf

${ }^{29}$ Akhtarul Wasey, (ed.), Mu'allim 'Așr: Said Nūrsi (New Delhi: AlBalagh Publications, 2015) p. 9. This 154 page book covers, among other topics, mostly the Life of Said Nürsi, The Dialogue between Islam and West, The Criticism of Philosophy, Islam and Modernity, and The Idea of Nationalism vis- wazala-vis Said Nürsi's views.

${ }^{30}$ See The Milli Gazette, Issue 1-15 March 2014, retrieved from http://www.milligazette.com/news/10037-conference-on-Nürsi-at-amu accessed on 25 December 2014

31 Speech delivered at the inaugural session in AMU's Kennedy Auditorium.

${ }^{32}$ In the entire event, the authors were themselves present there. Therefore most of the related information provided is taken from the statements recorded by the authors while the conference was ensuing.

${ }^{33}$ Retrieved from http://www.iikv.org/en/call-for-papers-4th-international -Nūrsi-studies-conference-in-india-2015 accessed on 26 December 2014

34 See more details about the programme of the conference on http://www.iikv.org/en/wp-content/uploads/Academic-Sessionsfinalized.pdf

${ }^{35}$ The authors were also among participants who presented the papers there.

${ }^{36}$ Details of the Propgramme http://www.iikv.org/en/international-Nūrsistudies-seminar-2016-programme

37 "International Workshop Programme \& Abstract Book in Kashmir/India," IFSC, 22 July 2014, retrieved from http://www.iikv .org/en/international-workshop-programme-in-kashmir-india accessed on 26 December 2014

38 See for more details, "Seminar on Nūrsi Begins at IUST," Rising Kashmir, retrieved from http://www.risingkashmir.com/seminar-onNūrsi-begins-at-iust/ accessed on 28 December 
39 It was his concise statement published by the daily newspaper, Greater Kashmir. "2-day seminar on Nūrsi begins," Greater Kashmir, 22 August 2014, retrieved from http://www. greaterkashmir. com/news/2014/ Aug/22/2-day-seminar-on-Nürsi-begins-58.asp accessed on 26 December 2014

${ }^{40}$ Ibid.

41 "Seminar on Nūrsi Begins at IUST," op. cit., http://www.risingkashmir .com/seminar-on-Nūrsi-begins-at-iust/

${ }^{42}$ Islamic Studies Departments of AMU and JMI have introduced in their recently revised curriculum (Masters Degree) the topics like contemporary personalities, life, thought, and works of Said Nūrsi, Islamic Revivalism in Turkey etc.

${ }^{43}$ For more details about Barla Publications and the books which they have published in various languages, see http://www. barlapublications. com/

${ }^{44}$ For more on this visit; http://www.barlapublications. com/index. Php ? $\mathrm{cPath}=24$

${ }^{45}$ Zubair Hamid-A PhD student enrolled in Aligarh Muslim University is currently working on the topic Islam and the West: A Critique of Said Nürsi

${ }^{46}$ Irfan Jalal-doing integrated Mphil-PhD in Islamic University of Science and Technology is carrying research on A Comparative Study of Nür Nama and Mathnavi Nüri

47 Enrolled in Jamia Millia Islamia as a PhD student, Gowhar Qadri Wani is currently doing research on Islam and Modernity: A Study with Special Reference to Said Nürsi's Risal-e-Nūr

${ }^{48}$.See for more details http://jmi.ac.in /upload/programme/cs fhl is ma islamic studies.pdf

${ }^{49}$ See Dr. Obaidullah Fahd, Faith-Knowledge: Perspective of Said Nürsi, (Aligarh, India: Department of Islamic Studies, AMU, Aligarh, 2016), 440pp.

${ }^{50}$ IFSC which is actively engaged in this task (since 1979) invites the reputed scholars who are well acquainted with life, thought, and works of Said Nūrsi. So, Colin Turner, Sukran Vahide, Prof. Ian S. Markham, Dr Ihsan Colak etc who have profusely worked and are regarded as experts on Said Nürsi and his Risale-i Nür, are regular hosts in most of their events. 